\title{
Dwuwiersz o Mieszku III Starym. Przyczynek do erudycji Mistrza Wincentego Kadłubka (IV, 22,5)
}

Zarys treści: W artykule podjęto analizę dwuwiersza Wincentego Kadłubka o Mieszku Starym szukającym stronników przeciwko Leszkowi Białemu. Pierwszym zaprezentowanym zagadnieniem jest refleksja nad literalnym znaczeniem strofy, a następnie źródeł, z których kronikarz mógł ją zapożyczyć. Ostatnią poruszoną kwestią jest sposób przedstawienia Mieszka w IV księdze Kroniki.

\begin{abstract}
In the article, I undertake an analysis of a distich by Master Vincentius Kadłubek about Prince Mieszko the Old seeking supporters against Leszek the White. First, I reflect on its literal meaning, and then attempt to answer the question from where the chronicler could have borrow it. Finally, I examine how Prince Mieszko was portrayed in the fourth book of the Chronicle.
\end{abstract}

Słowa kluczowe: Wincenty Kadłubek, genorbada, Mieszko III Stary, przysłowia średniowieczne, Uguccio z Pizy

Keywords: Vincentius Kadłubek, genorbada, Mieszko III the Old, medieval proverbs, Huguccio Pisanus

U kilkunastu zaledwie autorów piszących w pełnym średniowieczu występuje niezwykle rzadkie łacińskie słowo genorbada. Materiał źródłowy jest wprawdzie skromny, jednak nawet tak niewielka próbka pozwala dostrzec, że wyraz ten był zapisywany w różnych postaciach ortograficznych i nadawano mu dość szeroki wachlarz znaczeń, zarówno literalnych, jak i symbolicznych. Przyjrzyjmy się temu problemowi, za punkt wyjścia analizy obierając Kronikę Kadłubka ${ }^{1}$. Jak podaje Mistrz Wincenty, po śmierci Kazimierza Sprawiedliwego możni obrali na tron krakowski jego małoletniego syna, Leszka Białego. Odbyło się to z pominięciem wciąż żyjącego starszego brata zmarłego, Mieszka. Stary książę poczuł się oburzony tym, że pogwałcone zostało prawo pierworództwa, a los Królestwa złożony został w rękach młokosa ${ }^{2}$. Postanowił wówczas przeciągnąć na swoją stronę śląskich bratanków, Bolesława Wysokiego i Mieszka Plątonogiego. Jego starania o zmontowanie koalicji przeciw Leszkowi, uwieńczone bitwą mozgawską ${ }^{3}$, zostały przez kronikarza skwitowane następującym dwuwierszem:

\footnotetext{
${ }^{1}$ Literaturę na temat kronikarza i jego dzieła zestawiają: K. Kollinger, Vincentiana. Materiały do bibliografii, w: Onus Athlanteum. Studia nad Kronika biskupa Wincentego, red. A. Dąbrówka, W. Wojtowicz, Warszawa 2009, s. 476-527; W. Drelicharz, Idea zjednoczenia królestwa w średniowiecznym dziejopisarstwie polskim, Kraków 2012, s. 70-91.

2 Zob. K. Pawłowski, Retoryka starożytna w Kronice Wincentego Kadlubka. Sztuka narracji, Kraków 2003, s. 85 n.

${ }^{3}$ Od strony historii politycznej wraz z dalszą literaturą zob. M. Smoliński, Sojusze Mieszka III Starego przed bitwa mozgawska, „Przegląd Zachodniopomorski”, 50, 2006, nr 4, s. 83-105. O Mozgawie ostatnio zob. J. Banaszkiewicz, Narrator w przebraniu, czyli Mistrz Wincenty o bitwie mozgawskiej, w: Onus Athlanteum, s. 423-434.
} 
Pretentat precibus, pretio mercatur et ambit:

Scit bene murilegus, cuius gernaboda lambit ${ }^{4}$.

Wierszyk, a zwłaszcza jego drugi werset, przysporzył tłumaczom kroniki sporych problemów. Ksiądz Franciszek Salezy Czajkowski w ogóle go opuścił ${ }^{5}$, a nieprzetłumaczony pozostawił Hipolit Kownacki ${ }^{6}$. Omownie jego znaczenie wyłożyli Andrzej Józefczyk i Marceli Studziński:

Kusi prośbami, przyciąga pieniądzmi i błaga.

Wie jak kogo zajśćc

Nieco lepiej poradziła sobie z nim natomiast Brygida Kürbis:

Złotem kupuje, kusi prośbami, karku uniża,

Dobrze wie kot, czyje pyski obrosłe liże ${ }^{8}$.

Jak w przypisie wyjaśniła poznańska uczona, „genobardum to wyraz niezrozumiały, przekręcany przez kopistów”. Zdecydowała się go oddać jako „obrosły pysk”, idąc „za interpretacją A[ugusta] Bielowskiego", który tak właśnie objaśnił go we wzorowanym na Zeissbergu słowniczku, dołączonym do drugiego tomu Pomników dziejowych Polski ${ }^{9}$. Czy faktycznie jednak jest to „wyraz niezrozumiały”, w domyśle słowo hapax, które nie występuje u żadnego innego średniowiecznego autora? I czy jego znaczenie zostało prawidłowo wyłożone przez A. Bielowskiego i B. Kürbis? Z pewnością ma rację thumaczka, że był on „przekręcany przez kopistów”. Z rozpoznaniem w tej kwestii poczekajmy jednak do zebrania szerszego materiału. Trzeba też zaznaczyć, że w toku wykładu, w zależności od kontekstu, będziemy posługiwać się różnymi formami ortograficznymi słowa genorbada. Konsekwentnie natomiast używać będziemy formy pluralis, bo w takiej liczbie pojawia się ono niemal zawsze w przekazach źródłowych. Nie bez powodu zresztą, jak się jeszcze okaże.

Cóż zatem oznacza ten termin? By nie trzymać czytelnika w niepewności, poprzestańmy na razie na definicji podanej przez Mariana Plezię, który objaśnił go jako „broda” ${ }^{10}$. Jakkolwiek wydaje się ona poprawna, to nie oddaje jednak pełni znaczeń przypisywanych temu słowu. Aby się o tym przekonać, wystarczy poszukać innych przykładów jego użycia. Jakkolwiek jest to słowo bardzo rzadkie, to nie stanowi bynajmniej hapax legomenon. Oprócz Kadłubka podają je zależni od niego Dzierzwa" ${ }^{11}$,

${ }^{4}$ Magistri Vincentii dicti Kadłubek Chronica Polonorum, wyd. M. Plezia, w: MPH s.n., t. 11, Kraków 1994, lib. IV, cap. 22 , § 5, s. 178 .

5 Wincentego Kadtubka biskupa krakowskiego Historya Polska zkrocona, [tłum. ks. F.S. Czajkowski], Łowicz 1803, s. 190.

${ }^{6}$ Kronika Polska przez Dzierswę w końcu wieku XII napisana, [tłum. H. Kownacki], Warszawa 1823, s. 155 (Dzierzwa, jak zobaczymy, zapożyczył dwuwiersz od Kadłubka).

${ }^{7}$ Mistrza Wincentego, zwanego Kadlubkiem, biskupa krakowskiego, Kronika Polska z rękopisu Eugeniuszowskiego, wyd. A. Przezdziecki, tłum. A. J[ózefczyk], M. S[tudziński], Kraków 1862, s. 235.

${ }^{8}$ Mistrz Wincenty Kadłubek, Kronika polska, tłum. B. Kürbis, Wrocław 2003, s. 244; por. Myśli i nauki Mistrza Wincentego zwanego Kadlubkiem, wybór i tłum. B. Kürbis, Warszawa 1980, s. 71. Za przekładem B. Kürbis poszedł thumacz niemiecki: „Mit Bitten macht er die Probe, mit Geld kauft und geht umher, | gut weiß der Kater, wessen behaarte Mäuler er lecken muss"; Die Chronik der Polen des Magister Vincentius, tłum. E. Mühle, Darmstadt 2014, s. 385.

${ }^{9}$ Mistrz Wincenty Kadłubek, Kronika polska, s. 244, przyp. 269; A. Bielowski, Stowniczek wyrazów nieznajdujacych się w stownikach zwyczajnych, lub użytych w innem znaczeniu, w: MPH, t. 2, Lwów 1872, s. 450. O konieczności weryfikacji „słowniczka” pisał K. Pawłowski, Retoryka starożytna w Kronice, s. 127.

10 Stownik taciny średniowiecznej w Polsce, t. 4, red. M. Plezia, Wrocław 1975-1977, s.v. gernaboda, kol. 526.

${ }^{11}$ Chronica Dzirsvae, wyd., wstęp i przyp. K. Pawłowski, w: MPH s.n., t. 15, Kraków 2013, s. 73. O tym zabytku dziejopisarskim zob. J. Banaszkiewicz, „Kronika Dzierzwy”. XIV-wieczne kompendium historii ojczystej, Wrocław 1979, zwł. s. 26, gdzie mowa o tym, że Dzierzwa wiernie powtórzył za Kadłubkiem opowieść o próbach odzyskania władzy przez Mieszka; W. Drelicharz, Annalistyka małopolska XIII-XIV wieku. Kierunki rozwoju wielkich roczników kompilowanych, Kraków 2003, s. 333-373; tenże, Idea zjednoczenia królestwa, s. 295-315. 
a także XV-wieczny wrocławski kompilator cytatów z jego Kroniki ${ }^{12}$. Dwuwiersza o kocie nie recypowali jednak kronikarze śląscy i wielkopolski ani nie opatrzył go komentarzem Jan z Dąbrówki. Trzeba szukać zatem w utworach niezależnych od dzieła biskupa krakowskiego.

Definicję podaną przez M. Plezię potwierdza użycie formy przymiotnikowej przez Lamberta z Ardres. Odnotowuje on wśród panów Aalst niejakiego Baldwina Jednookiego. Jak wyjaśnia XII-wieczny kronikarz: „był on zwany Gernobodatus ze względu na długą brodę" ${ }^{3}$. Ten sam przydomek miał nosić zresztą Eustachy II hrabia Boulogne ${ }^{14}$. Czyżby wyjaśniało to kwestię? Niestety, komplikuje ją Oraculum angelicum, pseudoproroctwo przypisywane Cyrylowi z Konstantynopola. Ten tajemniczy przeor z góry Karmel miał je usłyszeć podczas odprawiania mszy i przetłumaczyć na łacinę. Komentarz do niego miał z kolei wyjść spod ręki samego Joachima z Fiore. W rzeczywistości zaczęło ono krążyć wśród franciszkańskich spirytuałów dopiero u schyłku XIII stulecia, i być może wówczas właśnie zostało spisane $^{15}$. Apokryf zasługiwałby na znacznie bardziej wnikliwą analizę niż bylibyśmy tutaj w stanie przeprowadzić. Tymczasem skupimy się na jednym zaledwie zdaniu z niego pochodzącym. W oryginale brzmi ono: „Quare Geronta geroneus sordens in fimo et opprobrio cum puellis genorboda eleuabit" ${ }^{16}$. W pierwszej kolejności uwagę zwraca aliteracja słów Geronta - geroneus - genorboda. Pod tymi ostatnimi kryją się najpewniej wąsy, które „,nastroszy głupi starzec ubrudzony gnojem i zhańbiony z dziewkami”. Utwierdza nas w tym komentarz Pseudo-Joachima, który napisał, że genorboda to „giorones sub naribus". Wyraz giorones został przez wydawcę opatrzony znakiem zapytania i wydaje się słowem hapax. Nie ma to wielkiego znaczenia wobec doprecyzowującego określenia „pod nozdrzami”, które jasno wskazuje na wąsy (ich właścicielem miał być, wedle komentatora, papież) ${ }^{17}$.

Sprawy nie rozstrzyga również poemat Doctrina Mensae Pseudo-Owidiusza, dotyczący zachowania przy stole. Znany jest wyłącznie z kilku późnośredniowiecznych kopii rękopiśmiennych, a spisany został w Hiszpanii w XII albo - w zależności od propozycji badawczych - w XIII w. ${ }^{18}$ Werset 59. przynosi zalecenie, by wino - metonimicznie określone jako „Bachus” - nie spływało biesiadnikom po genorbada ${ }^{19}$. Czyli po czym? Tekst Lamberta wskazywałby na brodę, tekst Cyryla zaś na wąsy. Obydwa rozwiązania pasowałaby przecież do kontekstu.

Kolejne wskazówki zawierają dwa przekazy narracyjne pochodzące z tego samego okresu co Kronika Kadłubka, czyli z przełomu XII i XIII w. Są to Descriptio Kambriae Giralda z Walii i anonimowa

12 J. Madej, Auctoritates Coronice Polonorum - o nietypowym wykorzystaniu Kroniki mistrza Wincentego zwanego Kadtubkiem, w: Causa creandi. O pragmatyce źródła historycznego, red. S. Rosik, P. Wiszewski, Wrocław 2005, s. 208.

${ }_{13}$ Lamberti Ardensis Historia comitum Ghisnensium, wyd. I. Heller, w: MGH SS, t. 24, Hannoverae 1879, cap. 122, s. 620: „Balduinum Luscum, propter barbe prolixitatem dictum Gernobodatum, Alostensis terre postea dominum”.

14 Tamże, cap. 110, s. 614: „Eustacii videlicet Gernobadati”. Francuska wersja tego przydomku, poświadczona dla czasów nowożytnych, to aux Guernons. Pod nią właśnie Eustachy występuje u XVII-wiecznego nadwornego historyka: A. du Chesne Tourangeau, Histoire généalogique des maisons de Guines d'Ardres, de Gand et de Coucy et de quelques autres families illustres, qui y ont esté alliées, Paris 1631, lib. III, cap. 2, s. 89. Jako de Gernons znany był Ranulf hrabia Cheshire (Chronicon Johannis Bromton, w: Historiae Anglicanae Scriptores Antiqui, wyd. R. Twysden, Londini 1652, kol. 1013), jako Othlesgernus zaś Wilhelm de Percy (Cartularium abbathiae de Whiteby ordinis s. Benedicti, wyd. J.C. Atkinson, Edinburghi 1879, s. 3); zob. też zestawienie: P.H. Reaney, R.M. Wilson, A Dictionary of English Surnames, wyd. 3, London-New York 2006, s.v. Garnon, Garnons, Gernon, Garnham, Grennan, s. 1274 n.

15 Zob. P. Piur, Vorbemerkung, w: Briechwechsel des Cola di Rienzo, t. 4, Berlin 1912, s. 223-228; A. Jotischky, The Carmelites and Antiquity. Mendicants and their Pasts in the Middle Ages, Oxford 2002, s. 134-136, 201-210; J.M. Sawilla, Antiquarianismus, Hagiographie und Historie im 17. Jahrhundert. Zum Werk der Bollandisten. Ein wissenschaftshistorischer Versuch, Tübingen 2009, s. 744 n., przyp. 335.

16 Oraculum angelicum Cyrilii, wyd. P. Piur, w: Briechwechsel des Cola di Rienzo, t. 4, cap. 5, s. 274.

17 Tamże, Kommentar, cap. 5, s. 276: ,genorboda: scimus hoc fore giorones [? - P.P.] sub naribus. Verumptamen quid hic voluit dicere spiritus nescio, nisi forte volumus exponere naturaliter, quod summus pontifex ex desolatione pignorum premissorum superius gioronos crisperabit sicut nos facimus, cum quempiam perdimus displicibilem".

18 Zob. E. Ruiz García, Saberes de oídas. De Doctrina Mensae, „Memorabilia. Boletín de Literatura Sapiencial”, 16, 2014, s. 4 (datuje poemat na połowę XII w.); M.L. Colker, Two More Manuscripts of the Doctrina Mense, „Manuscripta”, 32, 1988, nr 3, s. 202-205 (na XIII w.).

19 E. Ruiz García, Saberes de oídas, v. 59, s. 39: „Non infundantur hominis genorbada Bacho”. Zdaniem wydawczyni i thumaczki genorbada to „wąsy” (s. 49). 
De profectione Danorum in Hierosolymam. Girald - by wziąć go na pierwszy ogien - mocno podkreśla dzielność Walijczyków. Wywodzić się oni mieli od towarzyszy Eneasza i po swoich przodkach odziedziczyć szczególną skłonność do walki o wolność ojczyzny ${ }^{20}$. W związku z tym śmierć we własnym łóżku uchodzi u nich za powód do wstydu, a śmierć na polu bitwy stanowi powód do chwały. Co więcej, są bardziej zainteresowani wojną niż jakimkolwiek innym zajęciem, takim jak handel czy uprawa roli. Postawa ta jest u nich powszechna, niezależnie od kondycji społecznej. Każdy bowiem spośród nich ochoczo reaguje na dźwięk trąb wojennych. W czasie walki rzadko (jeśli w ogóle) używają uzbrojenia ${ }^{21}$. Po przedstawieniu zwyczajów bojowych Walijczyków przechodzi Girald do opisu ich wyglądu. Podaje, że „mężowie mają w zwyczaju golić brodę oprócz samych gernoboda. Obyczaj ten nie obowiązuje od niedawna, lecz sięga wstecz dawnych wieków: tak jak można wnieść z księgi o czynach Juliusza Cezara, napisanej przez niego samego. Znajdziesz tam i takie słowa: lud Brytów ogolony na całym ciele, z wyjątkiem górnej wargi”’22.

Mimo że Girald powołuje się na Cezara expressis verbis, to bynajmniej nie zapożyczył od niego słowa gernoboda. Boski Juliusz nie używa go bowiem. Mówi jedynie (Bellum Gallicum, V, 14), że Brytowie golą całe ciało oprócz głowy i wąsów ${ }^{23}$. Powinno to być dla nas wskazówką, jak autor Descriptio Kambriae rozumiał ten termin. Cytat z Wojny galijskiej jest z jednej strony zbieżny z przekazem Cyryla z Konstantynopola, a z drugiej zdaje się wchodzić w sprzeczność z własną wypowiedzią Giralda, z której wynikałoby raczej, że chodzi nie tyle o wąsy („superius labrum”), ile o jakąś część brody (,barbam [...] præter gernoboda solum”). Sam Girald nie widzi tutaj żadnej sprzeczności; co więcej, współcześni mu Walijczycy są tym samym ludem, o którym swego czasu pisał Cezar. Zwróćmy też uwagę, że skoro gernoboda są częścią brody, to nie mogą być - jak sugerują Lambert z Ardres i M. Plezia - jej synonimem. Odłóżmy na razie tę wątpliwość, poprzestając na stwierdzeniu, że mamy do czynienia z jakimś elementem męskiego zarostu. Co więcej - jak można wnosić z łącznego potraktowania dwóch osobnych rozdziałów utworu Giralda - miała być to swoista oznaka tożsamości i męstwa Walijczyków ${ }^{24}$, zakorzeniona zresztą w dawnej epoce (uchwytna wszakże w czasach Cezara i potwierdzona przez jego świadectwo). Spróbujmy wesprzeć tę interpretację przykładem porównawczym.

${ }^{20}$ Giraldi Cambrensis Descriptio Kambrice, w: Giraldi Cambrensis Opera, t. 6, wyd. J.F. Dimock, Rerum Britannicarum Medii Ævi Scriptores, London 1868, lib. I, cap. 8, s. 179-182. Na temat wiedzy etnograficznej Giralda zob. np. R. Bartlett, Medieval and Modern Concepts of Race and Ethnicity, „Journal of Medieval and Early Modern Studies”, 31, 2001, nr 1, s. 46; R. Mardsen, Gerald of Wales and Competing Interpretations of the Welsh Middle Ages, c. 1860-1910, „Welsh History Review", 25, 2011, nr 3, s. 315-321; O. Nash, Elements of Identity: Gerald, the Humours and National Characteristics, w: Gerald of Wales. New Perspectives on a Medieval Writer and Critic, red. G. Hanley, A.J. McMullen, Cardiff 2018, s. 203-219. Nie miałem dostępu do pracy: R. Bartlett, Gerald of Wales, 1146-1223, Oxford 1982.

${ }^{21}$ W podobny sposób Girald przedstawił zwyczaje bojowe Irlandczyków; zob. J. Banaszkiewicz, „Nadzy wojownicy” - o średniowiecznych pogtoskach dawnego rytu wojskowego (Prokopiusz z Cezarei, Pawet Diakon, Girald z Walii, Sakso Gramatyk i Gall Anonim), w: tenże, Takie sobie średniowieczne bajeczki, wprow. M. Tomaszek, Kraków 2012, s. $369-371$

22 Giraldi Cambrensis Descriptio Kambrice, lib. I, cap. 11, s. 185: „Barbam viri, præter gernoboda solum, radere solent. Et hanc non de novo, sed ab antiquo, longisque retro seculis, consuetudinem tenent: sicut ex libro de gestis Julii Cesaris, ab ipso conscripto, perpendi potest. Ubi et hæc verba reperies: Britonum gens omni parte corporis abrasa, præter superius labrum" (tłum. cytatów źródłowych, o ile nie zaznaczono inaczej, pochodzą od autora).

${ }^{23}$ „Omni parte corporis rasa praeter caput et labrum superius”; korzystałem z edycji internetowej: <http://www.thelatinlibrary. com/caesar/gall5.shtml\#14> [dostęp: 29.04.2018].

${ }^{24} \mathrm{Na}$ temat różnych form męskiego zarostu, ich określeń i kulturowego znaczenia zob. J.J. Arnold, Theoderic's Invincible Mustache, „Journal of Late Antiquity”, 6, 2013, nr 1, s. 152-183. W ostatniej kwestii uwagi przynoszą też: R. Bartlett, Symbolic Meanings of Hair in the Middle Ages, ,Transactions of the Royal Historical Society”, 4, 1994, s. 43-60; W. Pohl, Telling the Difference. Signs of Ethnic Identity, w: Strategies of Distinction. The Construction of Ethnic Communities, 300-800, red. W. Pohl, H. Reimitz, Leiden-Boston 1998, s. 51-61; A. Gronowska, Fabuly rycerskie w Gesta ducum sive principum Polonorum Galla Anonima na tle wybranych przyktadów piśmiennictwa średniowiecznego (do końca XIII w.), niepublikowana praca doktorska w Instytucie Kultury Polskiej UW, Warszawa 2009, s. 48-63; I. Wood, Hair and Beards in the Early Medieval West, „Al-Masāq”, 30, 2018, nr 1, s. 107-116; R. Kasperski, Kobiety z dtugimi brodami kontra mężczyźni z kobiecymi włosami, czyli nota o Origo gentis Langobardorum, w druku (dziękuję Autorowi za udostępnienie mi tego tekstu, jak również za cenne uwagi do niniejszego artykułu). 
Autor De profectione Danorum in Hierosolymam, będący Norwegiem albo Duńczykiem, przedstawia się nam jako frater $X$ canonicus. Jego dzieło traktuje o niezbyt udanym pod względem militarnym udziale kilku Skandynawów w III krucjacie ${ }^{25}$. Naszą uwagę przykuwa passus wprowadzony niegdyś do polskiej literatury przez Stellę M. Szacherską, która zidentyfikowała go jako najdawniejsze poświadczenie nazwy Półwyspu Helskiego ${ }^{26}$. Oto na wieść o upadku Jerozolimy Esbern Snare, brat arcybiskupa Absalona, wygłosił mowę mającą zachęcić zebranych do walki z poganami. Przywołał w niej mężne czyny Duńczyków dokonane w różnych odległych krajach, począwszy od Grecji, przez Italię, Normandię po Morze Bałtyckie. Przypomniał, że przed ich przodkami ugięli swoje karki nawet Rzymianie: „Jeśli chcesz, spytaj Longobardię, a znaczenie jej nazwy nawet przez chwilę nie zatai, że została przez nas podbita. Jak dobrze jest bowiem wiadome, zwą się Longobardami, to jest: długobrodymi, stąd że nasz pradawny zwyczaj, gdy ich pokonaliśmy, nakazywał nosić gemobodiam jak u lwów; naśladując ojczysty obyczaj, dziedzicznie posiedli też nazwę, i dobrze widać, że groza naszego ludu wstrząsnęła rzymskim męstwem"27.

Pokonanie Rzymian jest jednym z przykładów mężnej przeszłości, które miały zagrzewać Duńczyków do podjęcia walki o wyzwolenie Jerozolimy. Esbern daje w nim wyraz przekonaniu o duńskim pochodzeniu Longobardów, wywiedzionemu - podobnie jak etymologiczne objaśnienie ich etnonimu - z lektury Pawła Diakona ${ }^{28}$. Z jednej strony mówi o pokonaniu Rzymu („Romanamque fortitudinem terror gentis nostre concussisse dignoscitur”), z drugiej - retrogresywnie - o podbiciu „Longobardii". Chodzi tu jednak o rzymskie terytoria, które dopiero po duńskim podboju zyskały taką nazwęę .

${ }^{25} \mathrm{O}$ tej kronice zob. np. V. Skånland, Einige Bemerkungen zu der „Historia de profectione Danorum in Hierosolymam”, cz. 1: Mandant und Verfasser, „Symbolae Osloenses”, 33, 1957, s. 137-155; cz. 2: Textkritisches, „Symbolae Osloenses”, 36, 1960, s. 99-115; A.O. Johnsen, Ny tolkning av „,Historia de Profectione Danorum in Hierosolymam”, w: Från medeltid till välfärdssamhälle. Nordiska historikermötet i Uppsala 1974. Föredrag och mötesförhandlingar, Stockholm 1976, s. 507-527; K. Skovgaard-Petersen, A Journey to the Promised Land. Crusading Theology in the „Historia de profectione Danorum in Hierosolymam" (c. 1200), Copenhagen 2001.

${ }^{26}$ Zob. S.M. Szacherska, Nazwa Hel - ślad itinerarium battyckiego z XII w., w: Polska w świecie. Szkice z dziejów kultury polskiej, red. J. Dowiat i in., Warszawa 1972, s. 137-147.

27 De Profectione Danorum in Hierosolymam, wyd. M.C. Gertz, Scriptores Minores Historiæ Danicæ Medii Ævi, t. 2, København 1918-1920, cap. 5, s. 466: „Longobardiam, si uis, interroga, et statim sui nominis proprietate se deuictam a nostris non celabit; appellantur enim, sicut notissimum est Longobardi, id est: longam barbam habentes, eo quod antiquitas nostri habitus, cum eos uinceremus, more leonum gemobodiam producebat; qui paternam consuetudinem imitantes nomen hereditario iure possederunt, Romanamque fortitudinem terror gentis nostre concussisse dignoscitur".

${ }^{28}$ Pauli Historia Langobardorum, wyd. G. Waitz, w: MGH, Scriptores rerum Germanicarum in usum scholarum, t. 48, Hannoverae 1878, lib. I, cap. 1, s. 53; cap. 8, s. 58. Trzeba jednak zaznaczyć, że odwołanie do Historii Longobardów w tekście kroniki nie pojawia się ani w wypowiedzi Esberna (która jest w mowie niezależnej), ani w autorskim komentarzu do niej. Możemy zatem jedynie zakładać, że kronikarz czytał Pawła Diakona.

${ }^{29}$ Również Saxo Gramatyk, zapoznawszy się z dziełem Pawła Diakona, uznał Longobardów za krewniaków Duńczyków; zob. L.B. Mortensen, Saxo Grammaticus' View of the Origin of the Danes and His Historiographical Models, „Cahiers de l'Institut du Moyen-Âge Grec et Latin”, 55, 1987, s. 169-183. Jak podaje, za panowania króla Snio nastał w Danii wielki głód i nieurodzaj. Wówczas bracia Aggo i Ebbo postanowili zaradzić temu, zabijając wszystkich starców i dzieci, a niezdolnych do noszenia broni i uprawy roli wygnać z kraju. Gdy dowiedziała się o tym ich matka, Gambaruc, zabroniła im zabijania najsłabszych. Poradziła, by drogą losowania zdecydowano, kto ma opuścić kraj. Tak też się stało i część Duńczyków udała się na poszukiwanie nowych siedzib. Gdy dotarli oni do Gotlandii, za sprawą bogini Frigg przyjęli - Paulo teste - nową nazwę Longobardowie. Saxo nie objaśnia jej znaczenia, podaje jednak, że najpierw zastąpiła ona dawny etnonim samego ludu, a następnie wyparła nazwę dotychczasowych mieszkańców Italii, gdzie Longobardowie wreszcie się osiedlili; Saxo Grammaticus, Gesta Danorum. The History of the Danes, t. 1, wyd. K. Friis-Jensen, thum. P. Fisher, Oxford 2015, lib. VIII, cap. 13, § 1-2, s. 594, 596. Szczegóły opowieści Saxona (klęska żywiołowa, eksterminacja najsłabszych, opuszczenie dawnych siedzib w poszukiwaniu nowych za radą „matrony”) łudząco przypominają historię Galindów, która zakończyła się jednak zagładą tego plemienia; zob. P. Żmudzki, Agresja wobec kobiecych piersi $i$ wojownicy bez broni, czyli Piotr z Dusburga o spustoszeniu kraju Galindów, w: Świat średniowiecza. Studia ofiarowane Profesorowi Henrykowi Samsonowiczowi, red. A. Bartoszewicz i in., Warszawa 2010, s. 647-665. Natomiast w podobny sposób jak Esbern do longobardzkiej przeszłości odwołał się niejaki Rampho, bohater Kroniki Salernitańskiej: gdy Frankowie domagali się od Longobardów trybutu, princeps tych ostatnich zasięgnął rady u swoich ludzi. Rampho stwierdził, że nie godzi się ulegać roszczeniom, ponieważ „nasi przodkowie porzucili niegdyś swoje siedziby z powodu trybutu, jakiego domagali się od nich 
Nie powinno nas to zmylić: Rzymianie nie zasymilowali się bynajmniej z najeźdźcami, schodząc do statusu poddanych; ich potęga należy do przeszłości i już dawno temu musieli ustąpić miejsca komu innemu $^{30}$. Zarówno kraina, jak i jej nowi władcy zyskali nową nazwę. Pochodziła ona od obyczaju noszenia szczególnego zarostu. Wskutek uproszczenia przekazu geneza tego obyczaju została przedstawiona zgoła odmiennie niż w legendzie etnogenetycznej Longobardów. Nie był on bowiem efektem podstępu Frei, w wyniku którego Wodan nadał Winilom nazwę „Longobardowie”, stając się w ten sposób ich bóstwem opiekuńczym ${ }^{31}$, został on po prostu przejęty po duńskich przodkach i zapewne wciąż był żywy wśród współczesnych Esbernowi Duńczyków. Podobnie jak u Giralda z Walii, zwyczaj ten został bowiem określony jako dawny (,antiquitas nostri habitus”, „paterna consuetudo”) i jeszcze wyraźniej niż u tamtego powiązany z dzielnością przejawianą na polu bitwy.

Skupmy się jednak na użytym przez kronikarza rzadkim terminie. Jego kronika zachowała się w trzech kopiach rękopiśmiennych z XVII w., stąd wszelkie rozważania paleograficzne na temat kształtu jej tekstu będą niepewne ${ }^{32}$. Jej odpisy zgodnie podają formę gemobodiam, jednak wydawca emendował ją na gernobadiam, co miało zapewne upodobnić to słowo do postaci ortograficznych znanych skądinąd ${ }^{33}$. Rzecz w tym, że interesujące nas słowo zapisywane było na rozmaite sposoby i de facto trudno byłoby wskazać na jakąś jego kanoniczną formę. Oczywiście dwuliterowa zbitka $r n$ łatwo mogła zlać się w pojedynczą literę $m$, samogłoska $a$ zaś zmienić w $o$. Liczba mnoga znana skądinąd mogła przy tym ulec zamianie na pojedynczą. O jakiej części zarostu wszakże mowa? Sprawa wydaje się pod tym względem równie niejednoznaczna jak w Descriptio Kambriae. Z pewnością nie ma tu mowy u wąsach, o których pisali Girald i Cyryl. Zarówno etnonim Longobardów, jak i jego podana etymologia wskazują na długą brodę (longa barba). W oczach kronikarza nie zachodzi przy tym żadna sprzeczność między pojęciem brody a tym, co zostało określone jako gemobodia, tak jakby były to synonimy ${ }^{34}$. Udziela on nam jednak jeszcze jednej wskazówki, a mianowicie wiążącej te ostatnie z wyglądem lwów. Nie jest wszakże jasne, czy zwrot more leonum odnosi się do pokonania Rzymian przez Duńczyków, czy też na co wskazuje interpunkcja w wydaniu Martina C. Gertza - właśnie do noszonego przez zwycięzców zarostu. W tym drugim wypadku mielibyśmy do czynienia z odpowiednikiem lwiej grzywy, który tak czy inaczej - byłby oznaką męstwa Longobardów. Wskazuje na to wyraźnie kontekst opowieści, dotyczącej spektakularnych podbojów militarnych ${ }^{35}$.

Wandalowie” (,propriis aedibus patres nostri liquerunt propter uestigalia, quae Guandalis ab eis exposcebant”); Chronicon Salernitanum, wyd. G.H. Pertz, w: MGH SS, t. 3, Hannoverae 1839, cap. 40, s. 490; por. W. Pohl, Memory, Identity and Power in Lombard Italy, w: The Uses of the Past in the Early Middle Ages, red. Y. Hen, M. Innes, Cambridge 2004 , s. 26.

${ }^{30}$ Porównawczo zob. R. Kasperski, Reges et gentes. Studia nad dyskursem legitymizujacym władzę nad wspólnotami wyobrażonymi oraz strategiami ich konstruowania we wczesnym średniowieczu (VI-VII w.), Warszawa 2017, s. 77-117.

31 Origo gentis Langobardorum, wyd. G. Waitz, w: MGH, Scriptores rerum Langobardicarum et Italicarum, t. 1, Hannoverae 1878, s. 2 n.; Pauli Historia Langobardorum, lib. I, cap. 8, s. 58.

${ }^{32} \mathrm{O}$ tradycji rękopiśmiennej tej kroniki zob. K. Skovgaard-Petersen, Et håndskriftfund i Lübeck ca. 1620. Om den spinkle overlevering af to norske nationalklenodier, „Fund og Forskning”, 41, 2002, s. 107-127; С.Ю. Агишев, Теодорик Монах и его „История о древних норвежских королях”, Москва 2013, s. 48-92; R. Rutkowski, Norweska kronika Mnicha Teodoryka. Pótnocna tradycja historyczna wprowadzona w nurt dziejów powszechnych (koniec XII w.), w druku, rozdz. 1.1.

33 De Profectione Danorum in Hierosolymam, s. 466, przyp. 22.

${ }^{34}$ Por. uwagi na temat średniowiecznej etymologii: E.R. Curtius, Literatura europejska i lacińskie średniowiecze, thum. A. Borowski, Kraków 2005, s. 519-525; K. Pomian, Przeszłość jako przedmiot wiary. Historia i filozofia w myśli średniowiecza, wyd. 2, Warszawa 2009, s. 68 n., 103 n., 265 n.; J. Banaszkiewicz, Teoria etymologii ludowej a średniowieczne etymologizowanie, Kwart. Hist., 81, 1974, nr 3, s. 593-599; P. Żmudzki, Kulturowy kontekst nazw „Polanie”, „Polacy”, „Polska” w średniowiecznej historiografi polskiej i ruskiej, w: Symboliczne i realne podstawy tożsamości społecznej w średniowieczu, red. S. Gawlas, P. Żmudzki, Warszawa 2017, s. 183 n.

35 W dziejopisarstwie średniowiecznym, w ślad za Nowym Testamentem (1 P 5,8), posługiwano się figurą lwa jako symbolem siły i męstwa. Na przykładzie tekstu Galla Anonima zob. np. P. Żmudzki, Władca i wojownicy. Narracje o wodzach, drużynie i wojnach w najdawniejszej historiografii Polski i Rusi, Wrocław 2009, s. 85, 113 n., 292 n.; S. Wieczorek, ,, Omnibus omnia facta sum”. Na marginesie książi Tomasza Jasińskiego „O pochodzeniu Galla Anonima”, Kwart. Hist., 117, 2010, nr 4, s. 94; szerzej zob. S. Kobielus, Bestiarium chrześsijańskie. Zwierzęta w symbolice i interpretacji. Starożytność i średniowiecze, Warszawa 2002, s. 180-186. Niekiedy symbolem lwiej postawy czyniono właśnie jego grzywę. Przykładowo książę 
Przypis tekstowy sporządzony przez M.C. Gertza okazuje się niezwykle pouczający w ustaleniu znaczenia zajmującego nas terminu ${ }^{36}$. Jak wyjaśnia edytor, gernobadia to tyle co „długie wąsy” (mystacum prolixitatem). Powołuje się przy tym na du Cange'a, do którego monumentalnego dzieła również zajrzałem. Otóż zdaniem du Cange'a gernobada vel genorbada to synonim francuskiego słowa grenones, oznaczającego wąsy albo brodę kota bądź kozy. Francuski leksykograf, idąc za Ugucciem z Pizy, dopatrywał się w nim greckiego źródłosłowu genos, a także skojarzył go z francuskim guernon ${ }^{37}$. Herbert Douglas Austin zarzucił mu jednak zignorowanie faktu, że w słowie tym zawarty jest germański człon -bad-, -bod-, -bard-. W sumie mielibyśmy do czynienia z połączeniem dwóch germańskich wyrazów, oznaczających różne części męskiego zarostu. Zdaniem H.D. Austina źródłosłowu należy dopatrywać się w staroangielskim wang-beard, oznaczającym nic innego jak bokobrody ${ }^{38}$. Od strony filologicznej jest to z pewnością trafne spostrzeżenie. Trzeba jednak zwrócić uwagę, że takie rozumienie nie znajduje jednoznacznego potwierdzenia w przekazach źródłowych. Teksty Kadłubka i hiszpańskiego poety w ogóle nie udzielają żadnych wskazówek w tym względzie. Dla Lamberta z Ardres i Uguccia z Pizy był to po prostu synonim brody ${ }^{39}$, dla Cyryla zaś i jego komentatora - wąsów. Girald z Walii i brat X kanonik widzieli wreszcie w genorbada jakąś formę męskiego zarostu, wąsy albo brodę, ale niekoniecznie bokobrody - chyba że za takowe uznać niezgoloną część brody, o której pisał pierwszy, albo odpowiednik lwiej grzywy, o której mówił drugi. Charakterystyczne jest zresztą, że słowo to prawie zawsze występuje w pluralis, tak jakby oznaczało coś występującego w parach na twarzy noszącego je mężczyzny. Wydaje się w każdym razie, że było ono wieloznaczne i pozbawione skodyfikowanego precyzyjnie desygnatu. Objaśnienie H.D. Austina przyjmujemy zatem z pewną dozą ostrożności. Jednakże, nie ma co ukrywać, wydaje się ono znacznie lepsze od „obrosłego pyska”40.

Pozostańmy jednak jeszcze chwilę przy du Cange'u, ponieważ naprowadza on nas na dalszy trop. Zilustrował on mianowicie interesujące nas pojęcie dwoma passusami źródłowymi. Pierwszy pochodzi z przytaczanej wyżej chorografii Giralda z Kambrii. Drugim jest wers niemal identyczny z tym przytoczonym przez Kadłubka, aczkolwiek w odwrotnym szyku (murilegus bene scit zamiast scit bene murilegus). Trudno w tym momencie oprzeć się zdumieniu, że B. Kürbis nie zajrzała do tak podstawowej pomocy naukowej, jaką jest Glossarium du Cange'a. Jednak nie o polemikę z zasłużoną mediewistką tutaj chodzi, ani nawet o samo korygowanie sporządzonego przez nią thumaczenia. Trzeba mieć też na uwadze, że nie dysponowała ona tak rozwiniętymi narzędziami informatycznymi, jakie dziś nam służą. Zastanawia raczej, czy du Cange cytuje właśnie Kadłubka - wydaje się wszakże, że wniosek taki byłby przedwczesny. Świadczy przeciwko temu odmienny szyk wersetu, choć jest to z pewnością najsłabszy argument. Przede wszystkim jedyną edycją Kroniki polskiej, jaka ujrzała światło dzienne przed śmiercią du Cange'a, była editio princeps przygotowana do druku przez Jana Szczęsnego Herburta. Genorbada jednak w niej się nie pojawiają, zastąpione „kolanem” (genu), zupełnie zresztą zmieniającym sens przekazu ${ }^{41}$. W grę mogą wchodzić jeszcze jakieś znane na Zachodzie kopie rękopiśmienne,

Świętopełk ,jak lew wypuszczony ze swej klatki stał na arenie rycząc i ze zjeżoną grzywą oczekiwał na żer” (,sicut leo de sua emissus cavea in theatrum stat rugiens et erectis iubis expectat edulium”); Cosmae Pragensis Chronica Boemorum, wyd. B. Bretholz, w: MGH, Scriptores rerum Germanicarum. Nova Series, t. 2, Berolini 1923, lib. III, cap. 23 , s. 190.

${ }^{36}$ De Profectione Danorum in Hierosolymam, s. 466, przyp. 22.

${ }^{37}$ Ch. du Fresne du Cange, Glossarium medice et infirmce latinitatis, t. 4, Niort 1885, s.v. grani, s. 100; por. F. Kluge, Etymological Dictionary of the German Literature, thum. J.F. Davis, London 1891, s.v. granne, s. 123 n.; J.F. Niermeyer, Mediae latinitatis lexicon minus, t. 1, Leiden 1954, s.v. grano, s. 473; Á.R. Magnúsdóttir, La voix du cor. La relique de Roncevaux et l'origine d'un motif dans le littérature du Moyen Âge (XII ${ }^{e}-X I V^{\circledR}$ siècles), Amsterdam-Atlanta 1998, s. 312.

${ }^{38}$ H.D. Austin, Germanic Words in Uguiccione's Lexicon, „Speculum”, 23, 1948, nr 2, s. 280; por. G. Köbler, Mittellateinisches Wörterbuch, s.v. gernobada, <http://www.koeblergerhard.de/Mittellatein-HP/VorwortMlat-HP.htm> [dostęp: 8.04.2019].

${ }^{39}$ Uguccione da Pisa, Derivationes, t. 2, wyd. E. Cecchini i in., Firenze 2004, s.v. genos, s. 523: „Genos grece, latine dicitur barba, unde genorbodum" (z edycji tej miałem możliwość skorzystać dzięki uprzejmości dr. Antoniego Grabowskiego i mgr Anny Pomierny-Wąsińskiej). Pojawia się wątpliwość, czy słowo genorbodum jest synonimem genos i barba, czy może raczej ich połączeniem?

${ }^{40}$ Abstrahuję od tego, jaki wydźwięk miało słowo „pysk” w czasach A. Bielowskiego.

${ }^{41}$ Historia Polonica, Vincentii Kadlubkonis episcopi Cracoviensis, wyd. J.S. Herburt, Dobromili 1612, s. 537. 
choćby wiedeńskie ${ }^{42}$. Spróbujmy jednak pójść innym tropem. Du Cange expressis verbis podaje bowiem imię autora, od którego zapożyczył inkryminowany passus. Chodzi tu mianowicie o wspomnianego już Uguccia z Pizy i jego Derivationes. Wyjaśnił on, że odpowiednikami słowa genorbada są barba i grinnovus, a także podał przykład jego użycia w sentencji o kocie ${ }^{43}$. Ale i zmarły w 1210 r. Pizańczyk nie jest - jak się okazuje - jedynym autorem, u którego werset ów się pojawił. Poczynienie szerszego rozpoznania w tej kwestii rzuciłoby pewne światło na erudycję Mistrza Wincentego.

Kwerenda wykazała, że w średniowieczu rozpowszechnione było przysłowie o kocie dobrze wiedzącym, kogo liże po brodzie. Pojawia się ono w różnych florilegiach, poematach, itp. ${ }^{44}$ Da się wyróżnić dwa jego warianty - pospolity i wyrafinowany. W tym pierwszym, znanym choćby z Fecunda ratis Egberta z Leodium ${ }^{45}$, Florilegium z St. Omer $^{46}$ i dialogu Salomona z Marcolfem ${ }^{47}$, występują obok siebie słowa cattus, barba i lingo. $\mathrm{Z}$ naszego punktu widzenia istotna jest forma wyrafinowana, w której wymienione wyrazy zostały zastąpione przez murilegus, genorbada i lambo. Postać pośrednią przekazał angielski zbiór sentencji z początku XIII stulecia ${ }^{48}$. W wersji kompletnej natomiast, oprócz kronik Kadłubka i Dzierzwy oraz leksykonu Uguccia z Pizy, pojawia się ono jeszcze w pochodzącym z trzeciej ćwierci XII w. zbiorze sentencji angielskiego cystersa Serlona z Wilton ${ }^{49}$ oraz w trzech tekstach z XIII w.: w spisanych przez paryskich celestynów Proverbia rustici ${ }^{50}$, w niemieckim Liber Ioca$l i s^{51}$, wreszcie w przypisywanym samemu Robertowi Grosseteste poemacie kosmologicznym Carmen de mundo et partibus ${ }^{52}$.

Z powyższych analiz wynika, że słowo genorbada zostało użyte przez zaledwie kilkunastu autorów pełnego i późnego średniowiecza ${ }^{53}$ : przez Kadłubka oraz zależnych odeń Dzierzwę i wrocławskiego

42 Zob. M. Plezia, Wstęp, w: Magistri Vincentii dicti Kadlubek Chronica Polonorum, s. XXIV n.

${ }^{43}$ Uguccione da Pisa, Derivationes, t. 2, s.v. genos, s. 523: „Genos grece, latine dicitur barba, unde genorbodum, quod vulgo dicitur grinnovus, unde quidam »murilegus bene scit cuius genorboda lambit«”; por. C. Riessner, Die „,Magnae Derivationes" des Uguccione da Pisa und ihre Bedeutung für die romanische Philologie, Roma 1965, s. $130 \mathrm{n}$.

44 Zob. np. Th. Wright, The Domestication of Animals in the Middle Ages, „The Intellectual Observer”, 6, 1865, s. 325; F. Seiler, Deutsche Sprichwörterkunde, München 1922, s. 86 n.; A. Steiner, The Vernacular Proverb in Mediaeval Latin Prose, „The American Journal of Philology”, 65, 1944, nr 1, s. 42; H. Walther, Proverbia sensentiaeque latinitatis medii aevi, t. 2, Göttingen 1964, nr 15750, s. 1017. Wersja staroangielska: „wel wot hure cat whas berd he lickat”; zob. Middle English Dictionary, red. H. Kurath, Sh.M. Kuhn, Ann Arbor 1957, s.v. bērd, s. 738; R.H. Robbins, J.L. Cutler, Supplement to the Index of Middle English Verse, Lexington 1965, nr 3894.6, s. 444. Notabene żaden z cytowanych autorów nie zwrócił uwagi na dwuwiersz Kadłubka.

${ }^{45}$ Egberts von Lüttich, Fecunda ratis, wyd. E. Voigt, Halle a.S. 1889, v. 7, s. 4: ,ad cuius ueniat scit cattus lingere barbam”.

46 E. Voigt, Das Florileg von S. Omer, „Romanische Forschungen”, 6, 1891, z. 3, nr 175, s. 567: „,non cattus nescit, quam barbam lingere poscit".

47 J.M. Ziolkowski, Solomon and Marcolf, Cambridge (MA)-London 2008, nr 65b, s. 62: „bene videt cattus cui barbam lingit voluntarius" (miałem dostęp jedynie do części edycji zamieszczonej na stronie: <https://www.academia.edu/3049742/ Solomon_and_Marcolf> [dostęp: 12.04.2018]). Inny wydźwięk ma wersja polska: „z tym kot rad mieszka we zgodzie, kto mu się da lizać po brodzie"; Rozmowy, które miat król Salomon Mądry z Marchołtem grubym a sprosnym, w: Proza polska wczesnego renesansu. 1510-1550, oprac. J. Krzyżanowski, Warszawa 1954, s. 93; por. J. Krzyżanowski, U średniowiecznych źródet przystów polskich, „Pamiętnik Literacki”, 51, 1960, z. 3, nr 26, s. 85.

48 The Dialogue of Salomon and Saturnus, with an Historical Introduction, wyd. J.M. Kemble, London 1848, s. 61: „Murilegus bene scit cui barbam lambere suescit".

49 A.C. Friend, The Proverbs of Serlo of Wilton, „Mediaeval Studies”, 16, 1954, s. 198: „Li chat set ben ki barbe il lecch | Murilegus bene scit, cui gernoboda lambit $\mid$ Scis, cate, cui lingis barbam, cui murmura fingis $\mid$ Cui barbam fovit lingendo, catus bene novit".

${ }^{50}$ E. Voigt, Prouerbia Rustici, „Romanische Forschungen”, 3, 1887, v. 43, s. 638: „Murilegus bene scit, cuius gernoboda lambit”.

${ }^{51}$ Der Liber Iocalis, w: P. Lehmann, Mitteilungen aus Handschriften, t. 5, Sitzungsberichte der Bayerischen Akademie der Wissenschaften. Philosophisch-historische Abteilung, t. 4, München 1938, v. 512-513, s. 77: „Scit bene murilegus, cuius genorboda lingit; | sic et amicicias palpo cum divite fingit".

${ }^{52}$ Carmen de mundo et partibus. Ein theologisch-physikalisches Lehrgedicht aus der Oxforder Handschrift Bodleian Digby 41, wyd. A. Bergmann, Frankfurt 1990, v. 943-944, s. 122-123: „Murilegus bene scit, cuius gernobada lambit; | scitque puer, cuius ubera dente premit".

${ }^{53}$ Du Cange cytuje jeszcze następujący ciąg wyrazów, pochodzący zapewne z Olla patella Jana z Garlandii: „Fasces, patellae, postela, Gernobada, surae"; tenże, Glossarium medice, t. 4, s.v. grani, s. 100. 
kompilatora, przez Giralda z Walii, Uguccia z Pizy, brata X kanonika, przez Serlona z Wilton i domniemanego Roberta Grosseteste, przez paryskiego celestyna i hiszpańskiego poetę, a także niemieckiego autora Liber Iocalis. Osobne miejsce zajmują Cyryl z Konstantynopola i jego komentator. Nawet uwzględniając stan zachowania bazy źródłowej i braki erudycyjne niżej podpisanego, nie należy się zapewne spodziewać, by udało się odnaleźć dużo więcej przykładów. Ewentualne zawężenie materiału nie powinno być zatem traktowane jako ostateczne zamknięcie tematu. Dysponując wszakże tak skromną bazą źródłową, należy wysunąć wnioski na trzech płaszczyznach: filologicznej, erudycyjnej i historiograficznej.

Nie będąc mediolatynistą, mogę pokusić się jedynie o zestawienie form, w jakich to słowo występuje w różnych tekstach, zdobywając się przy tym jedynie na ostrożne spostrzeżenia filologiczne. W tym wypadku podstawę źródłową da się jednak dodatkowo rozszerzyć o odmienne przekazy rękopiśmienne. Rękopisy Kroniki Kadłubka podają co najmniej pięć różnych wariantów. W wydaniu M. Plezi znajdujemy cztery z nich: gernaboda, genaraboda, gneraboda i genorbada ${ }^{54}$, piąty podaje Aleksander Przezdziecki - genaboda ${ }^{55}$. U Dzierzwy występują bądź formy zapożyczone od Mistrza Wincentego (gernaboda, genorbada), bądź noszące znamiona abrewiacji paleograficznych, których nie biorę pod uwagę (gniboda, bnigoda $)^{56}$. U Serlona z Wilton, Giralda z Walii i w Proverbia rustici czytamy: gernoboda, u brata X kanonika: gemobodia, a w Liber Iocalis: genorboda, granobata i granolata ${ }^{57}$. Grosseteste podaje: gernobada. W różnych rękopisach Derivationes mamy: genorboda, generboda i genorbada ${ }^{58}$, w Doctrina Mensae: genorbada, genobodia, genebrodia, geneboda i gerolobodia ${ }^{59}$, wreszcie u Cyryla z Konstantynopola i w komentarzu do niego: genorboda, genorbida, gerobonda, gerrobundam i genoboda ${ }^{60}$.

Rozpoznajemy aż dziewiętnaście różnych form ortograficznych, co samo w sobie zdaje się świadczyć o obcości słowa względem leksyki łacińskiej ${ }^{61}$. Z jednej strony, jest ich zbyt wiele i są one zbyt zróżnicowane, by łatwo można było dopatrzyć się jakiejś reguły, a z drugiej próbka jest zbyt mała, by dało się ją opracować statystycznie. Niemniej można pokusić się o pewne ostrożne spostrzeżenia. Pomimo różnorodności form obserwujemy powtarzanie się niektórych spośród nich, co pozwala mówić o konwergencji zapisów. Najczęściej występującymi są formy: genorbada (czterokrotnie), genorboda i gernoboda (trzykrotnie) oraz gernaboda (dwukrotnie), zbliżone do występujących pojedynczo gernobada, generboda i gerobonda. Odnotujmy też przymiotnik gernobodatus (bądź gernobadatus), poświadczony przez Lamberta z Ardres. Zwykle mamy do czynienia ze słowem czterosylabowym, które jedynie w dwóch wypadkach rozrasta się do sylab pięciu (genaraboda, gerolobodia). Poza tym nie ma jednej reguły, jeśli chodzi o zestaw i kolejność liter w poszczególnych sylabach. Najbardziej stabilny pod tym względem jest pierwszy człon ge-, aczkolwiek i on w wiedeńskim kodeksie Kroniki Kadłubka przekształcił się w gne-, w rękopisach Liber Iocalis zaś w gra- (co zbliża całość do słowa grani). Również ostatni człon - $d a$ byłby niezmienny, gdyby nie przybrał formy -dia w kopiach De profectione Danorum in Hierosolymam i Doctrina Mensae (w pierwszym przypadku raczej -diae) i -ta w Liber Iocalis. W dwusylabowym członie centralnym dochodziło już do swobodnej zmiany kolejności samogłosek $a$, $o$, rzadziej $e$ i $i$, oraz spółgłosek $b, n, r$ (u Cyryla podwojonej), a niekiedy także $l$ i $m$, tak że można doliczyć się kilku jego postaci.

${ }_{54}$ Zob. Magistri Vincentii dicti Kadtubek Chronica Polonorum, s. 178, przyp. 22,5.

${ }_{55}$ Magistri Vincentii episcopi Cracoviensis Chronica Polonorum, wyd. A. Przezdziecki, Cracoviae 1862, s. 216.

${ }^{56}$ Chronica Dzirsvae, s. 73, wraz z przyp. h.

${ }^{57}$ Der Liber Iocalis, s. 77, przyp. 512.

${ }^{58}$ Uguccione da Pisa, Derivationes, t. 2, s.v. genos, s. 523, wraz z przyp. 122; por. H.D. Austin, Germanic Words, s. 279 n.

59 E. Ruiz García, Saberes de oídas, s. 39, przyp. 244.

${ }^{60}$ Briechwechsel des Cola di Rienzo, t. 4, s. 274, przyp. 3 oraz s. 276, przyp. 30-34.

${ }^{61} \mathrm{~W}$ klasycznej łacinie słowa na oznaczenie bokobrodów zresztą brak. Sydoniusz Apolinary przedstawia rzecz opisowo: „barba concavis hirta temporibus” (G.S. Apollinaris Sidonii Epistulae, wyd. Ch. Luetjohann, w: MGH, Auctores antiquissimi, t. 8, Berolini 1887, lib. I, ep. 2, § 2, s. 2), Izydor z Sewilli wspomina natomiast o noszonych przez Germanów ,granos et cinnibar" (Isidori Hispalensis episcopi Etymologiarvm sive Originvm libri XX, wyd. W.M. Lindsay, Oxonii 1911, lib. XIX, cap. 23, § 7, nlb.). Znaczenie tych terminów nie jest jednak dla nas jasne; zob. J.J. Arnold, Theoderic's Invincible Mustache, s. 163-166. 
Interesujące nas słowo odnaleźliśmy zatem w zaledwie kilkunastu przekazach. Fakt, że wszystkie pochodzą z XII-XIII w., i to na dodatek z różnych stron średniowiecznej Europy, daje do myślenia. Zastanawia geograficzny rozrzut badanych tekstów - od Hiszpanii do Polski, od Skandynawii do Ziemi Świętej i od Anglii do Italii - kontrastujący z ich bliskością czasową. Wydaje się bowiem, że słowo to było elementem zasobu leksykalnego kilku żyjących podówczas intelektualistów i poza transmisją rękopiśmienną ich tekstów szybko wyszło z użycia, ustępując miejsca innym, bardziej banalnym określeniom męskiego zarostu. Na dwuwiersz o Mieszku Starym powinniśmy spojrzeć wszelako nie przez pryzmat opowieści Giralda $\mathrm{z}$ Walii czy brata X kanonika, tylko takich przekazów, które podają przysłowie o kocie. Funkcjonowało ono już we wczesnym średniowieczu i dopiero w kompilacji Serlona z Wilton pojawiło się w nim słowo gernobada. Z pewną dozą ostrożności można sprowadzić do niej późniejsze przekazy $^{62}$. Nie dalej niż dwa pokolenia później sentencję zacytują mianowicie Uguccio z Pizy i Mistrz Wincenty, a jeszcze później - autorzy Carmen de mundo et partibus, Liber Iocalis oraz Proverbia rustici. Czy dałoby się zatem wskazać jakiś ośrodek intelektualny, będący wspólnym mianownikiem, w którym pojawiło się i z którego promieniowało to przysłowie? Otóż Mistrz Wincenty zdobywał szlify intelektualne gdzieś zagranicą - domyślano się, że w Bolonii, tudzież w Paryżu, a więc w tych samych ośrodkach, w których studiowali odpowiednio Uguccio i Serlo ${ }^{63}$. Na Francję wskazują również późniejsze Carmen de mundo et partibus oraz Proverbia rustici. Kadłubek zapoznałby się z takim zbiorem raczej w jakiejś szkole katedralnej czy klasztornej niż na jednym z ówczesnych ośrodków uniwersyteckich.

Wniosek, jaki się nasuwa, byłby wszakże następujący: dwuwiersz, w którym starający się pozyskać stronników Mieszko Stary został przyrównany do kota, nie jest oryginalną kompozycją Kadłubka. A ściśle rzecz biorąc, jedynie pierwszy jego werset (,pretentat precibus, pretio mercatur et ambit”) został jak się wydaje - ułożony przez Mistrza Wincentego, i to w taki sposób, by zrymował się z następnym (ambit - lambit). Ten drugi, ujęty w leoninową formę, był natomiast znanym w średniowiecznej Europie przysłowiem, z którym Kadłubek zetknął się zapewne w ramach edukacji zagranicznej i które spożytkował dla własnych celów. Zapewne nigdy nie uda się wskazać na bezpośrednie źródło, z którego je zapożyczył. Nie były nim z pewnością Proverbia rustici, niekoniecznie zaś zbyt późne, jak się wydaje, Derivationes, raczej jakaś niezidentyfikowana kompilacja przypominająca te pierwsze. Być może właśnie ta, która wyszła spod pióra Serlona, zachowana m.in. w paryskim kodeksie Ms. lat. 6765. Kronikarz zetknął się z takim zbiorem raczej w szkole klasztornej albo katedralnej aniżeli na uniwersytecie. W grę wchodzić może również obieg ustny. Przysłowia, nawet w łacińskiej postaci, mogły funkcjonować w potocznej komunikacji w kręgach, w których obracał się Kadłubek. Werset ten został zresztą w XV w. zdekontekstualizowany i na powrót stał się samoistną sentencją za sprawą anonimowego wrocławskiego kompilatora ${ }^{64}$.

Rzadkie słowo genorbada funkcjonowało w różnych kontekstach, jednak najistotniejsze są dla nas te przykłady, gdy występowało w przysłowiu o kocie. Wymusza to rozpatrywanie zagadnień erudycyjnych w kontekście zbliżonych przekazów. Inaczej bowiem niż u Giralda czy u skandynawskiego kanonika, w Kronice Kadłubka genorbada nie są oznaką męstwa odziedziczonego po wojowniczych przodkach, tylko atrybutem kogoś, kogo poparcie trzeba zdobyć pochlebstwami, obietnicami i kosztownościami. Kogoś obsadzonego zresztą w biernej roli. Tym samym przekazy te przynależą do różnych porządków, zarówno jeśli chodzi o zaplecze intelektualne, jak i ich znaczenie ideowe. Ów „myszołów”, który dobrze wiedział, kogo ma polizać, sam zapewne nie nosił bokobrodów i daleko mu było do lwów, na których swój zarost wzorowali Longobardowie ${ }^{65}$. Wskazują na to również inne przypadki użycia słowa

${ }^{62} \mathrm{Na}$ wpływ Serlona wskazuje A.C. Friend, The Proverbs of Serlo of Wilton, s. 180.

${ }^{63}$ O erudycji Kadłubka zob. np. O. Balzer, Studyum o Kadłubku, w: tenże, Pisma pośmiertne, t. 1-2, Lwów 1934-1935; B. Kürbisówna, Motywy makrobiańskie w Kronice mistrza Wincentego a szkoła Chartres, St. Źródł., 17, 1972, s. 67-79; K. Chmielewska, Rola wątków i motywów antycznych w „Kronice polskiej” Mistrza Wincentego zwanego Kadtubkiem, Częstochowa 2003; Z. Kałuża, Lektury filozoficzne Wincentego Kadlubka. Zbiór studiów, Warszawa 2014.

${ }^{64}$ J. Madej, Auctoritates Coronice Polonorum, s. 208.

${ }^{65}$ Por. A.C. Friend, The Proverbs of Serlo of Wilton, s. 198. Te oczywiste stwierdzenia pociągają za sobą określone konsekwencje dla wnioskowania komparatystycznego. W efekcie nie da się w sposób metodologicznie poprawny przypisać 
murilegus $\mathrm{w}$ tekście Mistrza Wincentego ${ }^{66}$. Kot jest u niego niegroźnym drapieżnikiem, przed którym strzec się winny krety ${ }^{67}$ i jaskółkii ${ }^{68}$, a którego z kolei nie muszą obawiać się orły ${ }^{69}$. Stąd też Mieszka Starego trudno porównać do duńskich pogromców Rzymian czy walijskich potomków Eneasza.

Udało nam się zatem zidentyfikować kolejny cytat w dziele Kadłubka. Pomimo rozwiniętych studiów erudycyjnych nad jego Kronika z jednej strony, a przysłowiami średniowiecznymi z drugiej, nikt tego wcześniej nie dokonał. Na tym osiągnięciu nie sposób wszakże poprzestać. Kontekst narracyjny Kroniki pozwoliłby zapewne stwierdzić, jaki był sens cytowanego przez Mistrza Wincentego przysłowia: czy odnosi się ono do doskonałego pochlebcy, czy do kogoś działającego podstępnie? Aby odpowiedzieć na to pytanie, musimy przyjrzeć się wizerunkowi Mieszka Starego na kartach Kroniki Kadłubka. Nie mamy bowiem do czynienia $\mathrm{z}$ sentencją jako taką, lecz cytatem włączonym w dziejopisarską narrację i w ramach szerszego kontekstu zyskującym określone znaczenia. Interesować nas będzie przede wszystkim korpus opowieści o późniejszych próbach odzyskania władzy przez Mieszka, do których należy również przekaz o Mozgawie. Próby te stanowią wszelako rezultat jego wcześniejszych poczynań. Trudno byłoby je zatem zrozumieć bez wniknięcia w szerszy wizerunek władcy na kartach Kroniki i rozeznania, z jakim typem bohatera mamy do czynienia. Tym bardziej że wskazówki dawane przez biskupa krakowskiego są niekiedy dwuznaczne i wzajemnie sprzeczne. Zastosuję zatem metodę thumaczenia „Kadłubka Kadłubkiem”.

Pierwsze wprowadzenie Mieszka na scenę wskazuje paradoksalnie na jego pozytywne przymioty. Gdy juniorzy wystąpili przeciwko Władysławowi Wygnańcowi, to właśnie Mieszko - „anime promotior et sermone torrentior" - namówił braci, by otwarcie uderzyli na seniora ${ }^{70}$. Zachęta spotkała się z uznaniem i doprowadziła do pomyślnego rezultatu. Zarówno Mieszko, jak i Bolesław Kędzierzawy określeni są jako principes strenuissimi $i^{71}$. Nie powinno nas to zmylić, skoro charakterystyki te kontrastują $\mathrm{z}$ dalszym przedstawieniem losów księcia. Mieszko Stary jest bowiem ewidentnie czarnym charakterem Kroniki. Na początku księgi IV Kadłubek informuje o objęciu przez niego władzy zgodnie z prawem sukcesyjnym. Pompatycznie wylicza jego sukcesy jako władcy Krakowa: jakich to on nie miał przyjaciół w krajach ościennych, jakich nie odniósł zwycięstw militarnych, jak liczne było jego potomstwo i jak szerokie były koligacje! Wystawiona laurka stanowi jednak wstęp do rychłego upadku. Kronikarz nie przypadkiem po dwakroć odwołał się do pojęcia (zmiennej w domyśle) fortuny. Powodzenie wyzwoliło bowiem w Mieszku zarozumiałość i gnuśność ${ }^{72}$. Opresyjna polityka wewnętrzna prowadzona

Kadłubkowym „bokobrodom” takich znaczeń, jakie nosiły one u Giralda z Walii czy u brata X kanonika, ponieważ pełnią one inną funkcję w ich narracjach. Nadinterpretacją byłoby również przypuszczenie, że w oczach Mistrza Wincentego bratankowie Mieszka cechowali się takim samym męstwem jak Walijczycy czy Longobardowie. Są oni bowiem bierni wobec schlebiającego im stryja. Obydwa przekazy etnograficzne mogą jedynie pomóc ustalić znaczenie słowa genorbada, a także jego rozpowszechnienie w średniowiecznej Europie, nie wnoszą natomiast zbyt wiele do interpretacji opowieści Kadłubka. Osobną kwestią jest, czy słowo to funkcjonowało w różnych tekstach niezależnie od obiegu sentencji o kocie, czy też dostało się do nich właśnie za jego pośrednictwem.

${ }^{66}$ Zob. Ch. du Fresne du Cange, Glossarium medice, t. 5, s.v. murilegus, s. 552 n.; O. Balzer, Studyum o Kadtubku, t. 2 , s. 13.

${ }^{67}$ Magistri Vincentii dicti Kadlubek Chronica Polonorum, lib. IV, cap. 19, § 10, s. 167: „Que talpa tam cecutiens proprio murilegum cauo inserare studuit?".

${ }^{68}$ Tamże, lib. II, cap. 15, § 10, s. 49: „Ad singulos oscinum hiatus, pullus hians hirundinis a murilego educabitur an non?”; cap. $28, \S 32$, s. 81 : „Si enim a nido hirundo murilegum [...] arcet”.

${ }^{69}$ Tamże, lib. III, cap. 14, § 6, s. 100: „Nam quis molestos estimet aquilis murilegos, tigribus cornupetas?”; zob. S. Kobielus, Bestiarium chrześcijańskie, s. 232-238.

70 Magistri Vincentii dicti Kadlubek Chronica Polonorum, lib. III, cap. 28, § 5, s. 121.

${ }_{71}$ Tamże, § 9, s. 122; por. E. Skibiński, Walka o władzę w kronice Mistrza Wincentego. Mieszko Stary i Kazimierz Sprawiedliwy, w: Onus Athlanteum, s. 49 n.; J. Banaszkiewicz, Uczta rozrachunku (Quentin Tarantino, Wincenty Kadtubek, Bruno z Kwerfurtu, Richer z Reims). Krótko o pewnym schemacie narracyjnym racjonalizujacym przedstawiana rzeczywistość, w: Świat średniowiecza, s. 638, wraz z przyp. 11.

${ }^{72}$ Magistri Vincentii dicti Kadlubek Chronica Polonorum, lib. IV, cap. 2, § 1-6, s. 130 n.; por. E. Skibiński, Mieszko czy Kazimierz? W sprawie sporu o inspiratora mistrza Wincentego, w: Nihil superfluum esse. Studia z dziejów średniowiecza ofiarowane profesor Jadwidze Krzyżaniakowej, red. J. Dobosz, J. Strzelczyk, Poznań 2000, s. 173 n.; tenże, Walka o władze w kronice, s. 50. 
przez jego doradców obróciła się przeciwko niemu ${ }^{73}$. Książę został obciążony winą za ich poczynania: otóż mądry władca nie powinien na coś takiego pozwolić, przymykając oczy na niedolę poddanych ${ }^{74}$. Jak dowiadujemy się z dalszego ciągu Kroniki, Mieszko nadużył swojej władzy pryncypackiej ${ }^{75}$. Ucisk trwał w najlepsze i doprowadził do zawiązania spisku w celu zastąpienia go Kazimierzem Sprawiedliwym. Najmłodszemu z synów Krzywoustego udało się podejść pod mury Krakowa i został radośnie powitany przez strzegących grodu, którzy złożyli mu wiernopoddańczy pokłon ${ }^{76}$. Mieszko - ironicznie scharakteryzowany jako „summe magnanimitatis princeps” - nie docenił wagi niebezpieczeństwa. Było już jednak za późno na to, by zaradzić sytuacji. W efekcie odsunęli się od niego wszyscy jego poplecznicy, z synem Odonem na czele. Osamotniony i opuszczony przez wiarołomnych krewnych (którzy zostali obciążeni winą za jego obalenie), osiadł wówczas wraz z młodszymi synami w jakimś granicznym grodzie ${ }^{77}$.

Instruktywne są dla nas zwłaszcza trzy opowieści o kolejnych próbach odzyskania władzy nad Krakowem, nie tylko dlatego, że zostały one skonstruowane w podobny sposób jak przekaz wyjściowy, ale przynoszą także charakterystyki działań Mieszka. Powtarza się w nich słabość militarna rekompensowana przebiegłością, próby zdobycia popleczników, wiarołomstwo. Próby, które - co już mniej istotne z naszego punktu widzenia - każdorazowo okazywały się nieskuteczne. Za pierwszym razem księciu udało się zdobyć kolejne grody w Wielkopolsce, z Gnieznem na czele, ku czemu Kazimierz dał mu ponoć skrycie sposobność ${ }^{78}$. Powodzenie w drobnej sprawie wzbudziło apetyt na więcej. Ponieważ jednak

${ }^{73}$ Magistri Vincentii dicti Kadlubek Chronica Polonorum, lib. IV, cap. 2, § 7-21, s. 131-134; por. np. S. Gawlas, O ksztalt zjednoczonego Królestwa. Niemieckie władztwo terytorialne a geneza społeczno-ustrojowej odrębności Polski, wyd. 2, Warszawa 2000, s. 79-82; P. Żmudzki, Vincentius's Construct of a Nation. Poland as res publica, w: Writing History in Medieval Poland. Bishop Vincentius of Cracow and the "Chronica Polonorum”, red. D. von Güttner-Sporzyński, Turnhout 2017, s. 181.

${ }^{74}$ Magistri Vincentii dicti Kadłubek Chronica Polonorum, lib. IV, cap. 2, § 22-31, s. 134-136. Nawet jeśli Kadłubek mówi o działaniach doradców Mieszka (uiri Belial), to i tak jego właśnie obciąża odpowiedzialnością za ich rezultaty (§23, s. 134); zob. K. Pawłowski, Retoryka starożytna w Kronice, s. 147; E. Skibiński, Walka o władzę w kronice, s. 50-53; odmiennie: J. Bieniak, Mistrz Wincenty o współczesnych mu Piastach, w: Europa Środkowa i Wschodnia w polityce Piastów, red. K. Zielińska-Melkowska, Toruń 1997, s. 39 n.; tenże, Mistrz Wincenty w życiu politycznym Polski przełomu XII i XIII wieku, w: Mistrz Wincenty Kadtubek. Człowiek i dzieło, pośmiertny kult i legenda, red. K.R. Prokop, Kraków 2001, s. 38-42.

75 Jest to opinia włożona w usta Kazimierza Sprawiedliwego; Magistri Vincentii dicti Kadlubek Chronica Polonorum, lib. IV, cap. 11, § 2, s. 151; por. J. Bieniak, Mistrz Wincenty w życiu politycznym, s. 38; K. Pawłowski, Retoryka starożytna w Kronice, s. 149.

76 Magistri Vincentii dicti Kadlubek Chronica Polonorum, lib. IV, cap. 4-6, s. 137-145.

77 Tamże, cap. 7, s. 145-147. B. Kürbis oddała ten zwrot jako „ogromnej siły ducha książę” i trafnie skomentowała go jako ironiczny; Mistrz Wincenty Kadłubek, Kronika polska, s. 194, wraz z przyp. 90. Inaczej sądził J. Bieniak, który odczytywał go dosłownie. Tymczasem charakterystyka ta zyskuje właściwe znaczenie w kontekście niewczesnej reakcji księcia na przybycie Kazimierza. Możliwe zresztą, że kronikarz użył tu rzeczownika magnanimitas w znaczeniu „pycha”, a nie „wielkoduszność”. A nawet jeśli pozostać przy tradycyjnym jego rozumieniu, to i tak średniowieczni autorzy często obdarzali krytykowane przez siebie postaci pozytywnymi z pozoru określeniami; por. np. R. Michałowski, Zjazd gnieźnieński. Religijne przesłanki powstania arcybiskupstwa gnieźnieńskiego, Wrocław 2005, s. 378; P. Żmudzki, Władca i wojownicy, s. 423 n. J. Bieniak sądził ponadto, że rzekome niespójności w wizerunku Mieszka da się wyjaśnić zmianami sytuacji politycznej w trakcie prac nad kroniką; tenże, Mistrz Wincenty o współczesnych mu Piastach, s. 46-52; tenże, Mistrz Wincenty w życiu politycznym, s. 37 n.; por. M. Przybył, Mieszko III Stary, Poznań 2002, s. 162. Wszakże portret władcy jest dopracowany, a to, że dochodzi do jego upadku wynika z podkreślonego dwukrotnie przez Kadłubka obrotu fortuny; por. też P. Żmudzki, Pierwsza bitwa Kazimierza Sprawiedliwego, czyli żelazne reguły prezentacji wojennego debiutu wielkiego bohatera (Kadtubek, ks. IV, rozdz. 14), w: Europa barbarica, Europa christiana. Studia mediaevalia Carolo Modzelewski dedicata, red. R. Michałowski i in., Warszawa 2008, s. 316 n.

78 Jest to nawiązanie do uprzedniej wypowiedzi Kazimierza, który podkreślał, że ciąży na nim dług wdzięczności wobec brata i że tamtemu należy się zwrot ojcowizny, nie należy się natomiast powrót do dzielnicy senioralnej, nad którą nadużył był władzy; Magistri Vincentii dicti Kadlubek Chronica Polonorum, lib. IV, cap. 11, § 1-2, s. 151. Wdzięczność Kazimierza miała zatem swoje granice, czego zrazu nie docenił J. Bieniak, mówiąc, że Mieszko „roztropnie ułatwił [młodszemu bratu] objęcie należnej [...] dzielnicy”; tenże, Mistrz Wincenty o współczesnych mu Piastach, s. 48; por. jednak tenże, Mistrz Wincenty $w$ życiu politycznym, s. 38, gdzie pojawiła się już uwaga o uprzednim nadużyciu władzy. Zresztą cała wypowiedź świadczy bardziej o wspaniałomyślności Kazimierza niż o przymiotach Mieszka, który zaraz potem zdradził brata. 
nie dysponował on odpowiednimi siłami, odwołał się wówczas do podstępu (,,plus ingenio, plus arte contendit”), pozorując, jakoby wcale nie chodziło mu o Kraków ${ }^{79}$. Chytrze udało mu się także obrócić łatwowiernego młodszego brata przeciwko Bolesławowi Wysokiemu. Grał jednak na dwa fronty, pozyskując innych stronników, których zaczął z kolei nastawiać przeciwko Kazimierzowi ${ }^{80}$. I wszystko poszłoby zgodnie z planem, gdyby zamek, w którym obradowali jego poplecznicy, nie zawalił się Boskim zrządzeniem, co też ostudziło ich dalsze zapędy. Kronikarz podkreśla tym samym, że Kazimierzowi sprzyjała Opatrzność, której powinien być wdzięczny ${ }^{81}$.

Przy okazji drugiej próby odzyskania pryncypatu dowiadujemy się, że Mieszko nie działał siłą, tylko podstępem, co zresztą Mistrz Wincenty traktuje z pewnym zrozumieniem ${ }^{82}$. Dychotomia vis industria jasno wskazuje, że nie przypadkiem władca został uprzednio przyrównany właśnie do kota. W każdym razie Mieszko pozyskał wówczas stronników, z księżną Heleną na czele, przekonując ich, że wcale nie chodzi mu o władzę dla samej władzy, tylko o dobro Królestwa. Gdy wpuszczono go do Krakowa, szybko zapomniał o złożonych przyrzeczeniach, za co został po raz kolejny zrzucony $\mathrm{z}$ tronu ${ }^{83}$. Ale zaraz potem znów uciekł się do podstępu. Zdołał bowiem przekonać księżną wdowę, że tym razem wywiąże się ze swoich zobowiązań wobec Leszka. Sytuacja się powtórzyła, i zapewne zostałby ponownie wygnany, gdyby nie przyszła po niego śmierć ${ }^{84}$.

Widać wyraźnie, że Mieszko Stary, próbując odzyskać władzę nad Krakowem, za każdym razem postępował wedle podobnego scenariusza. Trudno wobec tego nie zgodzić się z Jackiem Banaszkiewiczem, że książę został przez Mistrza Wincentego sportretowany jako mąż „przebiegły i wiarołomny"85. Janusz Bieniak natomiast celnie mówi o upadku Mieszka i - nawiązując do Stanisława Smolki - wspomina o jego „próżnych zabiegach o powrót na ogólnopolski tron" ${ }^{86}$. Charakteryzuje go wreszcie jako „żądnego władzy starca, który z chytrością i intrygami nadrabiać musi niedostatek sił" ${ }^{87}$. Opinie te rzucają też światło na sens analizowanego przez nas przysłowia o kocie liżącym bokobrody. Niekoniecznie mówią nam one natomiast, jaki Mieszko był „naprawdę”.

\section{A distich about Mieszko III the Old. A contribution to the erudition of Master Vincentius Kadłubek (IV, 22,5)}

Summary: The subject of the analysis is a distich by Master Vincentius Kadłubek, comparing Prince Mieszko III the Old seeking supporters against Prince Leszek the White to a cat. First, I try to establish the exact meaning of the extremely rare word of genorbada used by the chronicler. For this purpose, I refer to other contemporary source texts in which it was used (Lambert of Ardres, Cyril of Constantinople, Gerald of Wales, and the anonymous De profectione Danorum and Doctrina mensae). This term, of Germanic origins, undoubtedly meant some part of the male beard, probably the sideburns, which in the texts of Gerald and Scandinavian anonymous were a sign of warlike peoples. Then I attempt to answer the question where Kadłubek borrowed this distich from. I was able to establish that it was a popular proverb about the cat in medieval Europe, appearing in the most similar form in Serlo of Wilton, Huguccio Pisanus, and in several thirteenth-century texts. Although it is difficult

\footnotetext{
${ }^{79}$ Magistri Vincentii dicti Kadlubek Chronica Polonorum, lib. IV, cap. 12, § 1-6, s. 152 n.; por. K. Pawłowski, Retoryka starożytna w Kronice, s. 165; M. Przybył, Mieszko III Stary, s. 117-120.

${ }^{80}$ Magistri Vincentii dicti Kadlubek Chronica Polonorum, lib. IV, cap. 12, § 7-8, s. 153.

81 Tamże, § 9-11, s. 153 n.

${ }^{82}$ Tamże, cap. 25, § 2-3, s. 187: „Quod quia uiribus assequi nequit, uiris ac robore inpar, industrie beneficio rem aggredi meditatur. Sepe namque omnibus maiores uiribus uires habet industria, ideoque maiorum prius animos quadam benignitate pretemptat, conciliat et ad suum consuadet propositum".

83 Tamże, § 3-13, s. 187-189.

${ }^{84}$ Tamże, § 14-19, s. 189 n.

${ }^{85}$ J. Banaszkiewicz, Polskie dzieje bajeczne Mistrza Wincentego Kadtubka, wyd. 2, Wrocław 2002, s. 318.

${ }^{86}$ S. Smolka, Mieszko Stary i jego wiek, Warszawa 1881, s. 283.

87 J. Bieniak, Mistrz Wincenty o współczesnych mu Piastach, s. 47 n.; tenże, Mistrz Wincenty w życiu politycznym, s. 37 n. Kwestią drugorzędną dla mnie pozostaje, w którym momencie narracji Kadłubka można mówić o „upadku” czy „nieoczekiwanej przemianie" Mieszka.
} 
to indicate a direct source (Serlo?), the chronicler had to come across this proverb at some foreign monastery or cathedral school. Adapting it to his own purposes, he included the proverb in his narrative of aging Mieszko, who cunningly tried to gain supporters to regain lost power over Krakow.

Nota o autorze: dr Rafał Rutkowski, współpracownik Instytutu Historii im. Tadeusza Manteuffla Polskiej Akademii Nauk w Warszawie. Zainteresowania badawcze: historia historiografii średniowiecznej, historia średniowiecznej Skandynawii.

Author: Rafał Rutkowski, PhD, employed at the Tadeusz Manteuffel Institute of History, Polish Academy of Sciences. His research interests cover: history of medieval historiography, history of medieval Scandinavia.

Instytut Historii im. Tadeusza Manteuffla Polskiej Akademii Nauk

Rynek Starego Miasta 29/31

00-272 Warszawa

e-mail: rr.rutkowski@wp.pl

\section{Bibliografia}

\section{Źródła}

Carmen de mundo et partibus. Ein theologisch-physikalisches Lehrgedicht aus der Oxforder Handschrift Bodleian Digby 41, wyd. A. Bergmann, Frankfurt 1990

Chronica Dzirsvae, wyd., wstęp i przyp. K. Pawłowski, w: MPH s.n., t. 15, Kraków 2013

De Profectione Danorum in Hierosolymam, wyd. M.C. Gertz, Scriptores Minores Historiæ Danicæ Medii Ævi, t. 2, København 1918-1920

Friend A.C., The Proverbs of Serlo of Wilton, „Mediaeval Studies”, 16, 1954, s. 179-218

Giraldi Cambrensis Descriptio Kambrice, w: Giraldi Cambrensis Opera, t. 6, wyd. J.F. Dimock, Rerum Britannicarum Medii Ævi Scriptores, London 1868

Lamberti Ardensis Historia comitum Ghisnensium, wyd. I. Heller, w: MGH SS, t. 24, Hannoverae 1879

Der Liber Iocalis, w: P. Lehmann, Mitteilungen aus Handschriften, t. 5, Sitzungsberichte der Bayerischen Akademie der Wissenschaften. Philosophisch-historische Abteilung, t. 4, München 1938

Magistri Vincentii dicti Kadlubek Chronica Polonorum, wyd. M. Plezia, w: MPH s.n., t. 11, Kraków 1994

Mistrz Wincenty Kadłubek, Kronika polska, tłum. B. Kürbis, Wrocław 2003

Oraculum angelicum Cyrilii, wyd. P. Piur, w: Briechwechsel des Cola di Rienzo, t. 4, Berlin 1912

Ruiz García E., Saberes de oídas: De Doctrina Mensae, „Memorabilia. Boletín de Literatura Sapiencial”, 16, 2014, s. $1-60$

Uguccione da Pisa, Derivationes, t. 1-2, wyd. E. Cecchini i in., Firenze 2004

Voigt E., Prouerbia Rustici, „Romanische Forschungen”, 3, 1887, s. 633-641

\section{Opracowania}

Arnold J.J., Theoderic's Invincible Mustache, „Journal of Late Antiquity”, 6, 2013, nr 1, s. 152-183

Austin H.D., Germanic Words in Uguiccione's Lexicon, „Speculum”, 23, 1948, nr 2, s. 273-283

Balzer O., Studyum o Kadlubku, w: tenże, Pisma pośmiertne, t. 1-2, Lwów 1934-1935

Banaszkiewicz J., Polskie dzieje bajeczne Mistrza Wincentego Kadlubka, wyd. 2, Wrocław 2002

Bieniak J., Mistrz Wincenty o wspótczesnych mu Piastach, w: Europa Środkowa i Wschodnia w polityce Piastów, red. K. Zielińska-Melkowska, Toruń 1997, s. 33-52

Bieniak J., Mistrz Wincenty w życiu politycznym Polski przełomu XII i XIII wieku, w: Mistrz Wincenty Kadtubek. Człowiek i dzieło, pośmiertny kult i legenda, red. K.R. Prokop, Kraków 2001, s. 21-48

Drelicharz W., Idea zjednoczenia królestwa w średniowiecznym dziejopisarstwie polskim, Kraków 2012

Du Cange Ch. du Fresne, Glossarium medice et infirmce latinitatis, t. 1-10, Niort 1883-1887

Gawlas S., O ksztalt zjednoczonego Królestwa. Niemieckie władztwo terytorialne a geneza społeczno-ustrojowej odrębności Polski, wyd. 2, Warszawa 2000

Gronowska A., Fabuly rycerskie w Gesta ducum sive principum Polonorum Galla Anonima na tle wybranych przykładów piśmiennictwa średniowiecznego (do końca XIII w.), niepublikowana praca doktorska w Instytucie Kultury Polskiej UW, Warszawa 2009 
Kasperski R., Reges et gentes. Studia nad dyskursem legitymizującym władzę nad wspólnotami wyobrażonymi oraz strategiami ich konstruowania we wczesnym średniowieczu (VI-VII w.), Warszawa 2017

Kobielus S., Bestiarium chrześcijańskie. Zwierzęta w symbolice i interpretacji. Starożytność i średniowiecze, Warszawa 2002

Pawłowski K., Retoryka starożytna w Kronice Wincentego Kadtubka. Sztuka narracji, Kraków 2003

Przybył M., Mieszko III Stary, Poznań 2002

Skibiński E., Mieszko czy Kazimierz? W sprawie sporu o inspiratora mistrza Wincentego, w: Nihil superfluum esse. Studia z dziejów średniowiecza ofiarowane profesor Jadwidze Krzyżaniakowej, red. J. Dobosz, J. Strzelczyk, Poznań 2000, s. 167-174

Skibiński E., Walka o wtadze w kronice Mistrza Wincentego. Mieszko Stary i Kazimierz Sprawiedliwy, w: Onus Athlanteum. Studia nad Kronika biskupa Wincentego, red. A. Dąbrówka, W. Wojtowicz, Warszawa 2009, s. 47-56 Walther H., Proverbia sensentiaeque latinitatis medii aevi, t. 1-6, Göttingen 1963-1969

Żmudzki P., Władca i wojownicy. Narracje o wodzach, drużynie i wojnach w najdawniejszej historiografii Polski i Rusi, Wrocław 2009 